\title{
Ward outings: providing patients with meal support in the real world
}

\author{
Heather Litchfield \\ From 2015 ANZAED Conference: Riding the Waves to Recovery \\ Surfers Paradise, Australia. 21-22 August 2015
}

Ward outings provide patients the opportunity to practice what they have learnt during their inpatient admission in a real-life context, to learn to feel comfortable eating out in public. The ward outing is for patients that are progressing well and have demonstrated that they can manage their meal plans on the unit and on leave.

The outing provides patients with an opportunity to challenge their eating disorder thoughts and beliefs around certain foods, by providing patients flexible options, whether the challenge is eating a sandwich in public, tackling a fear food or, having a meal that has not been eaten since the onset of a patient's illness.

During the outing the social worker provides patients with a positive social experience over a meal and activity of the patient's choosing. They conduct themselves as a positive role model; demonstrating to patients how to manage eating their meal in public, providing patients with a high level of support, encouraging the patients to order an appropriate meal, or, to consider challenging their eating disorder cognitions around certain foods. This is with the aim that patients will become more flexible with meal choices and be more willing to challenge their eating disorders.

Submit your next manuscript to BioMed Central and take full advantage of:

- Convenient online submission

- Thorough peer review

- No space constraints or color figure charges

- Immediate publication on acceptance

- Inclusion in PubMed, CAS, Scopus and Google Scholar

- Research which is freely available for redistribution

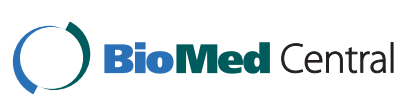

(c) 2015 Litchfield This is an Open Access article distributed under the terms of the Creative Commons Attribution License (http:// creativecommons.org/licenses/by/4.0), which permits unrestricted use, distribution, and reproduction in any medium, provided the original work is properly cited. The Creative Commons Public Domain Dedication waiver (http://creativecommons.org/publicdomain/ zero/1.0/) applies to the data made available in this article, unless otherwise stated. 